\title{
Teachers' Motivation for Teaching in Higher Education: Portuguese Validation of a Questionnaire
}

\author{
Leandro Silva Almeida ${ }^{1}$ \\ Maria Alfredo Moreira ${ }^{1}$ \\ Suzana Nunes Caldeira ${ }^{2}$ \\ Sara Medeiros Soares ${ }^{2}$ \\ Natascha van Hattum-Janssen ${ }^{3,4}$ \\ Gerda J. Visser-Wijnveen ${ }^{5}$
}

\begin{abstract}
Motivation for teaching is key in the establishment and further development of high-quality higher education, as it affects teachers' investment in quality learning experiences for their students, as well as institutional efficacy and well-being. This study aimed to validate a questionnaire, originally developed in Belgium, designed to evaluate three dimensions (self-efficacy, interest, and effort) of intrinsic motivation for teaching for a different national population. The sample consisted of 616 academics working in public higher education institutions in Portugal. Confirmatory factor analysis was conducted and internal consistency of items analyzed. The results show that the original dimensionality of the construct is confirmed in the Portuguese teachers' sample. Motivation for teaching in the Portuguese context is primarily explained by the following factors: personal efficacy, interest in the task, and effort placed on teaching responsibilities. A difference was found in that personal efficacy could not be divided in context and general personal efficacy.
\end{abstract}

Keywords: intrinsic motivation, teachers, higher education

\section{Motivação dos Professores para o Ensino na Educação Superior: Validação Portuguesa de um Questionário}

\begin{abstract}
Resumo: A motivação para ensinar é fundamental para o desenvolvimento de ensino superior de qualidade, pois determina o investimento dos professores em experiências de aprendizagem de qualidade para os seus estudantes, bem como a eficácia e bem-estar institucionais. O estudo teve por objetivo a validação de um questionário, originalmente desenvolvido na Bélgica, destinado a avaliar três dimensões (autoeficácia, interesse e esforço) sobre motivação intrínseca para ensinar, para uma população nacional distinta. A amostra é composta por 616 acadêmicos que trabalham em instituições públicas de ensino superior em Portugal. Realizou-se a análise fatorial confirmatória e analisou-se a consistência interna dos itens para cada uma das dimensões avaliadas. Os resultados mostram que a dimensionalidade original do constructo é confirmada na amostra portuguesa, sendo a motivação para o ensino explicada principalmente pelos seguintes fatores: eficácia pessoal, interesse pelo trabalho e esforço nas responsabilidades de ensino. Não foram encontradas diferenças entre eficácia pessoal geral e eficácia pessoal contextual.
\end{abstract}

Palavras-chave: motivação intrínseca, professores, ensino superior

\section{Motivación de los Profesores para la Enseñanza en la Educación Superior: Validación Portuguesa de un Cuestionario}

\begin{abstract}
Resumen: La motivación para la enseñanza es clave en el desarrollo de una educación superior de calidad, porque determina la inversión de los profesores en experiencias de aprendizaje de calidad para sus estudiantes, así como la eficacia institucional y el bienestar. El estudio tuvo como objetivo validar un cuestionario, desarrollado originalmente en Bélgica, destinado a evaluar tres dimensiones (autoeficacia, interés y esfuerzo) sobre la motivación intrínseca para la docencia, en una población nacional distinta. La muestra consistió en 616 académicos que trabajan en instituciones públicas de educación superior en Portugal. Se realizó un análisis factorial confirmatorio y se analizó la consistencia interna de los ítems por dimensión. La dimensionalidad original del constructo se confirma en la muestra portuguesa. La motivación para enseñar en este contexto se explica principalmente por los siguientes factores: eficacia personal, interés en la tarea y esfuerzo en la enseñanza. La diferencia que se encontró es que la eficacia personal no pudo dividirse en contextual y general.
\end{abstract}

Palabras clave: motivación intrínseca, profesores, educación superior

${ }^{1}$ University of Minho, Braga, Portugal

${ }^{2}$ University of Azores, Ponta Delgada, Portugal

${ }^{3}$ Saxion University of Applied Sciences, Enschede, Netherlands

${ }^{4}$ University of Twente, Enschede, Netherlands

${ }^{5}$ Anton de Kom University of Suriname, Paramaribo, Suriname

Correspondence address: Leandro Silva Almeida. Universidade do Minho. Centro de Investigação em Educação. Campus de Gualtar, Braga - 4710-057,

Portugal. E-mail: leandro@ie.uminho.pt
Teachers' motivations for teaching in higher education are rarely studied (Gunersel, Kaplan, Barnett, Etienne, \& Ponnock, 2016). The quality of teaching is often a neglected aspect of research and policy and too often a disinvestment on the part of teachers and institutions. Moreover, research is often prioritized at the expense of teaching (Visser-Wijnveen, Stes, \& Van Petegem, 2014). 
However, motivation for teaching is an important aspect for the quality of the learning experience offered at this level, as teachers' perceptions, beliefs, and intentions, which are connected to their motivation, influence their classroom behaviors, as well as their students' motivation (Gunersel et al., 2016; Han \& Yin, 2016; Katz \& Shahar, 2015; Palermo \& Thomson, 2019). Highly motivated teachers present higher levels of job engagement and satisfaction (Inigo \& Raufaste, 2019; Ramos et al., 2018; Skaalvik \& Skaalvik, 2017) and are more productive (Machado-Taylor et al., 2016).

In pedagogical contexts, motivation has been an object of study for decades, particularly related to students' academic success within primary and secondary education. Despite the low number of studies on higher education teachers' intrinsic motivation to teach, the available literature shows that motivated teachers are more productive (MachadoTaylor et al., 2016; Saglam, 2007) and show more goaloriented and persistent behaviors, even when facing challenges and difficulties (Slavich \& Zimbardo, 2012). It also shows that the performance of the academic staff determines, to a large extent, the quality of the student experience in higher education and has a significant impact on student learning. The literature also points to the relevance of the academic context (climate, interpersonal and social interactions, justice perceptions) for teachers' motivation (Aldridge \& Fraser, 2016; El Alfy \& David, 2017; Viseu, Jesus, Rus, Canavarro, \& Pereira, 2016). These aspects are particularly relevant in higher education where there is a highly competitive context, and the staff is often required to handle multiple tasks and conflicting goals, which clearly affects their investment in teaching and thus their motivation for it. As a key resource to the good functioning of the institution and to the quality of the student's experience, teaching motivation is central to any debate on quality assurance mechanisms. In addition, studying the intrinsic motivation of higher education teachers is necessary to more accurately predict and enhance positive teaching behavior, time investment, and innovation in teaching (Esdar, Gorges, \& Wild, 2015; Schneider \& Preckel, 2017).

To promote the development of research in this area, it is important to ensure reliable and valid instruments to assess teachers' motivation in higher education contexts. To this end, building on a previous study on the development and validation of the "Motivation for Teaching in Higher Education Questionnaire" (Visser-Wijnveen, Stes, \& Van Petegem, 2012), this study seeks to validate this questionnaire for the Portuguese population. It builds on and expands previous studies on this theme in international contexts (Esdar et al., 2015; Gunersel et al., 2016; Visser-Wijnveen et al., 2014), as well as on an under researched national context (Machado-Taylor et al., 2016). In doing so, it addresses the call for more validation studies of instruments studying teacher motivation by, among others, Han and Yin (2016) and Lam (2012). In Han and Yin's (2016) comprehensive review of teacher motivation studies, only five out of 130 studies studied 'instruments', with the majority focusing on either 'language teacher motivation' or 'influencing factors'.

Many studies assessing teaching motivations see selfefficacy as an essential part of teacher motivation in higher education, building on the Self-Determination Theory and on the Social Cognitive Theory (Dybowski \& Harendza, 2015; Dybowski, Sehner, \& Harendza, 2017). More specifically, Dybowski and Harendza (2015) developed and validated an instrument to assess physicians' teaching motivations in undergraduate medical education, including the constructs of perceived competence and self-efficacy. However, their focus was on hospital-teaching and on critical situations specific to medical education, such as those including patients. The specificity of this instrument makes it not applicable for a wider university audience. Other studies use motivation questionnaires that focus on the links between job motivation and job satisfaction among the academic staff (Stankovska, Angelkoska, Osmani, \& Grncarovska, 2017) or between motivation programs and work effort (Blaskova, Blasko, Figurska, \& Sokol, 2015). These questionnaires do not specifically address the motivation for teaching itself but, instead, focus on the (pre)conditions for being motivated for teaching, like salary, promotion, rewards, procedures and supervision (Stankovska et al., 2017), or methods and techniques to develop motivation (Blaskova et al., 2015); therefore, they are not well-equipped for the task at hand.

For this study, the Motivation for Teaching in Higher Education questionnaire by Visser-Wijnveen et al. (2012) was chosen. This questionnaire was specifically developed for higher education and has been applied in several contexts either in full, in part, or in an adapted form (El Alfy \& David, 2017; Kheir-Faddul \& Dănăiaţă, 2019; UiterwijkLuijk, Krüger, Zijlstra, \& Volman, 2017; Visser-Wijnveen et al., 2014). In the Israeli context, it showed a positive correlation with transformational leadership styles and a negative correlation with both transactional and laisserfaire leadership styles (Kheir-Faddul \& Dănăiaţă, 2019), which suggests that the questionnaire is context sensitive. This was also confirmed by a study in the United Arab Emirates (El Alfy \& David, 2017) in which perceived organizational justice was related to motivation as measured by the effort and interest scales. While the internal consistency of the scales was normally calculated (Cronbach's alphas varying between .72 and .84) in these studies, so far no study could be identified that validated the questionnaire in a different context with a larger sample. Neither did the studies address points raised by VisserWijnveen et al. (2012) such as ways to reduce the skewness of two scales, the cultural and higher education system issues that might explain some of the results, and the position of outcome efficacy and teaching efficacy within the concept of motivation. Han and Yin (2016) warned that previous studies on teacher motivation were overly dependent on single site studies. Even though the original questionnaire was applied in four different institutions, they were all located in the same 
city and were part of a local network. Therefore, this study sought to include academics from all public universities and polytechnics within one country.

The instrument under study includes self-efficacy, interest and effort as key clusters with regard to intrinsic motivation for teaching in higher education (Visser-Wijnveen et al., 2012). Each factor will be briefly discussed.

The belief in one's ability to take action in given situations - Self-efficacy - is related to both personal and social characteristics that influence a person's behavior (Bandura, 1997), as well as to local culture and history (Yada et al., 2019), school climate and job satisfaction (Aldridge \& Fraser, 2016). This construct has been developed as a result of studies that involved academic realizations, attributions of success and failure, goal setting, social comparisons, problem solving, career choice, teaching and teacher education, among others (Bandura, Azzi, \& Polydoro, 2008). Several authors make a distinction between personal efficacy and teaching efficacy: the first refers to the teacher's beliefs about one's ability to display specific teaching behaviors that are under one's control; the second may be defined as the teachers' beliefs in one's own capabilities to promote and produce an effect on students' performance, softening or overcoming personal or environmental limitations (Armor et al., 1976). Teachers who believe in their own abilities for teaching also show a set of other professional qualities that positively impact on student motivation and academic success (Miller, Ramirez, \& Murdock, 2017; Slavich \& Zimbardo, 2012; Zee \& Koomen, 2016). Based on the work done by the Rand Corporation (Armor et al., 1976), Gibson and Dembo (1984) added the concept of outcome efficacy. Outcome efficacy corresponds to the teachers' beliefs that if they implement their teaching skills, the environment can be controlled and influenced by one's actions in order to achieve the desired result (Gibson \& Dembo, 1984). Synthetizing, we could say that personal efficacy brings up the judgments that teachers have on whether they are good/competent teachers; teaching efficacy relates to the teachers' perceptions that their teaching can counteract the effects of external influences on their students' achievement; finally, outcome efficacy corresponds to the teachers' beliefs in their ability to act on the environment and change it, in order to get desired outcomes on student results.

A second dimension of teachers' intrinsic motivation concerns interest, a variable that has been considered more recently within the scope of studies on teacher motivation (Schiefele \& Schaffner, 2015). Within 'interest', individual and situational interest are distinguished: individual interests are relatively stable and relate to the intrinsic value of a given activity, situational interests are mainly created by contextual factors and, thus, are more related to extrinsic factors (Schiefele, 2009); interests generally result from combining an individual disposition, the content of the object of interest, and the context characteristics (O'Keefe, Dweck, \& Walton, 2018). Interests stimulate choices, mold decisions, and take part in action planning with a view to attaining those choices through the decision-making process associated with them. Generally, interests generate positive emotions and contribute to facilitating a positive climate or ethos (Zee \& Koomen, 2016).

Finally, individuals have a tendency to interpret their environment by attributing causes to what happens to them (Weiner, 2000). One of those causes is effort, among others, such as capability, helping others, and task characteristics. As an internal and controllable matter, effort is often more constructive for helping to advance learning (Garcia \& Boruchovitch, 2014). Effort is one of the ways to operationalize human motivation, as it implies investment, purposeful and persistent action, goal-achievement, and resilience in facing difficulties (Deci \& Ryan, 2008; Pintrich \& Schunk, 2002). Thinking that failure comes from lack of effort, instead of lack of ability, has completely different consequences for task outcome and for self-confidence and awareness (Weiner, 2000). Specifically, to think about failure and associate it with one's own lack of ability activates feelings of incompetence and resignation, facilitating task disengagement. Thoughts of failure associated with lack of effort, on the other hand, activate guilt and shame, generating energy conducive to productive investment.

With this reference framework, this study aimed to validate a questionnaire, originally developed in Belgium, designed to evaluate three dimensions (self-efficacy, interest, and effort) of intrinsic motivation for teaching for a different national population, i.e., Portuguese academics.

\section{Method}

\section{Participants}

The sample of 616 responses collected from all over the country had the following characteristics: the majority was female $(56.5 \%)$, of Portuguese nationality $(91.1 \%)$, possesses a PhD (73.7\%; Master's degree: 21.1\%; 5-year Bachelor's degree [Licenciatura]: 5.2\%) and works in Universities $(54.9 \% ; 45.1 \%$ in Polytechnic Institutes). The teachers' ages were between 25 and $74(M=46.8$; $S D=8.49)$. Their teaching years in higher education varied highly: from $1(n=10)$ to $43(n=1)(M=18.0 ; S D=8.81)$. These teachers worked in almost all scientific domains: Social and Economic Sciences (36.4\%); Physical, Mathematical and Engineering Sciences (30.2\%); Arts and Humanities (18.8\%); Life and Health Sciences (14.1\%), and others, such as Multimedia, and Tourism areas $(0.5 \%)$.

\section{Instruments}

Motivation for Teaching in Higher Education Questionnaire. A multidimensional instrument developed by Visser-Wijnveen et al. (2012) for measuring higher education teachers' motivations for teaching. This questionnaire was validated for higher education teachers in the Dutch (Flemish) speaking part of Belgium, presenting adequate levels of reliability and construct validity (Visser-Wijnveen et al., 2012). 
Thus, for the adaptation and validation of the Portuguese version, we kept the same factors and items as the original validated Dutch language questionnaire. For each item, the respondents were asked to position themselves using a 6-point Likert type scale ( 1 would be 'Strongly disagree' and 6 'Strongly agree'), as recommended by Visser-Wijnveen et al. (2012) to reduce the tendency for a skewed distribution, in contrast to the original 4-point Likert type scale.

For its translation, the original Dutch questionnaire was used, supported by its translation to English. Subsequently, judgement on the intelligibility of the items was carried out by a Portuguese scholar with extensive experience in research on pedagogy in higher education who proposed several adjustments. The foreseen ambiguities in the meaning of several items were discussed with one of the authors of the original version and minor changes were made accordingly. Then a group of four academics analyzed the items and suggested the removal of some, due to repetition and intelligibility issues. These adjustments resulted in the reduction of the original 34 items to 25 in the Portuguese version. The numbering of the items in both versions and their sub-scales are presented in Table 1.

Table 1

Comparison between the Dutch and the Portuguese Questionnaires

Item

Our item Original

No. item No.

Personal efficacy: context

I am absolutely confident that I have a sufficiently good knowledge of the content to teach this course module. [Tenho a certeza que possuo os conhecimentos suficientes da matéria para ensinar esta unidade curricular/ Ik heb er alle vertrouwen in dat ik voldoende inhoudelijke kennis heb om het onderwijs van dit opleidingsonderdeel te verzorgen]

I am sure that I have the necessary skills to teach this course module. [Tenho a certeza que possuo as capacidades necessárias para ensinar esta unidade curricular/ Ik ben er zeker van dat ik over de nodige vaardigheden beschik om dit opleidingsonderdeel te verzorgen]

I am absolutely confident that I have sufficient didactic knowledge to teach. [Tenho toda a confiança no meu conhecimento didático para ensinar esta unidade curricular/ Ik heb er alle vertrouwen in dat ik voldoende didactische kennis heb om onderwijs te verzorgen]

I am absolutely confident that my students are learning something from me in this course module. [Tenho a certeza que os alunos aprendem comigo nesta unidade curricular/ Ik heb er alle vertrouwen in dat studenten van mij leren in dit opleidingsonderdeel]

Personal efficacy: general

I think that I am quite a good teacher. [Acho que sou bastante eficaz a ensinar/ Ik denk dat ik vrij goed ben in lesgeven]

Now that I've been teaching for a while, I think that I am a competent teacher. [Avaliando o meu percurso docente, sinto-me um(a)professor(a) competente/ $\mathrm{Nu}$ ik reeds een tijdje lesgeef, voel ik mij daarin competent]

I am satisfied with my competencies as a teacher. [Estou satisfeito(a) com as minhas competências para ensinar/ Ik ben tevreden over mijn competenties inzake lesgeven]

I have a talent for teaching. [Tenho vocação para ensinar/ Ik ben onderlegd in lesgeven]

\section{Interest}

I really enjoy teaching. [Gosto muito de dar aulas/ Ik geef zeer graag les]

Teaching is fun. [Dar aulas é, para mim, divertido/ Lesgeven is leuk]

Teaching is a boring activity. [Dar aulas é aborrecido/ Lesgeven is een vervelende activiteit] (R)

Teaching is a very interesting activity. [Dar aulas é uma atividade muito interessante/ Lesgeven is een zeer interessante activiteit]

Teaching is fairly enjoyable. [Dar aulas é, para mim, bastante agradável/ Lesgeven is vrij plezierig] 
Table 1

Continuation

Item

Our item Original

No. item No.

Effort

I put a lot of energy into my teaching. [Dedico-me muito às tarefas de ensino/ Ik steek veel energie in mijn onderwijstaak]

15

12

mijn onderwijstaken]

It's important to me to be a good teacher. [É importante para mim dar boas aulas/ Ik vind het voor mezelf belangrijk om goed les te geven]

I don’t put a lot of effort into my teaching. [Não me esforço muito nas minhas tarefas de ensino/ Ik steek niet zoveel energie in mijn onderwijstaak] (R)

\section{Teaching efficacy}

How much a student learns is determined more by innate talent than by teaching. [O que um aluno aprende é mais determinado pela sua capacidade natural do que pela atividade de ensino/ Hoeveel een student leert is sterker bepaald door genetische aanleg dan door onderwijs]

How well a student performs is more strongly determined by genetic factors than by teaching. [A qualidade do desempenho dos(as) alunos(as) deve-se mais às suas capacidades genéticas do que à atividade de ensino/ Hoe goed een student presteert is sterker bepaald door erfelijkheidsfactoren dan door onderwijs]

If a student performs well, this is usually due to his or her innate abilities. [Se um(a) aluno(a) tem um bom desempenho é geralmente devido às suas capacidades inatas/ Als een student goed presteert is dat veelal te wijten aan zijn/haar aangeboren capaciteiten]

\section{Outcome efficacy}

When a student performs better, very often this is just because I have made an extra effort. [Se os resultados dos(as) alunos(as) melhoram, é porque eu descobri uma abordagem de ensino mais eficaz/ Wanneer een student beter

presteert dan gewoonlijk is dat vaak omdat ik een extra inspanning leverde]

When a student achieves a better score than he or she usually gets, this is often because I have found a better way to help that student. [Quando um aluno meu ou uma aluna minha tem um desempenho melhor do que o habitual, esse desempenho deve-se ao meu maior esforço/ Wanneer een student een betere score behaalt dan hij/zij gebruikelijk doet, is dat vaak omdat ik een betere manier vond om die student te begeleiden]

If students' scores improve, that is usually because I have found a more effective teaching approach. [Quando um(a) aluno(a) obtém um melhor resultado do que o habitual é geralmente porque encontrei uma forma melhor de o(a)

Note. $\mathrm{R}=$ Reverse coded item

\section{Procedures}

Data collection. All academics in public higher education institutions in Portugal were invited via email to take part in an online survey. The invitation included a link to the website on which the online survey was presented. It was sent to several public higher education institutions in the country, using a snowballing technique. These institutions included Polytechnic Institutes and Universities, using convenience sampling procedures. The first part concentrated on the respondents' background characteristics (age, gender, nationality, academic degree, teaching experience, scientific area, sub-system [polytechnic or university], and geographic area [North, Center, South, islands]). The second part focused on their motivations for teaching and included 25 items as stated. We received 616 valid responses.

Data analysis. In order to evaluate the theoretical model underlying the original Dutch questionnaire, a confirmatory factor analysis (CFA) was conducted. Due to problems of skewness and kurtosis in several items, the WLSMV (Weighted Least Squares Means and Variance adjusted) estimator was considered, using the MPlus program (version 8.3). Several usual CFA indexes were considered to evaluate the model's goodness-of-fit: Chi-square over degree of freedom $\left(X^{2} / d f\right)$, Comparative Fit Index (CFI), Tucker-Lewis fit Index (TLI), Root Mean Square Error of Approximation (RMSEA), and SRMR (Standardized Root Mean Square Residual). The fit was considered good for $X^{2} / d f$ 
equal to or less than 3.0 (Iacobucci, 2009), CFI equal to or above .90 (Bentler \& Bonett, 1980), RMSEA below .06, and SRMR below .08 (Hu \& Bentler, 1999). In face of the ordinal nature of the items, internal consistency was calculated with ordinal $\alpha$ (Oliden \& Zumbo, 2008) and $\omega$ (Raykov, 2001), where values above .75 are adequate.

\section{Ethical Considerations}

Informed consent to use the data from the questionnaire for the purposes of this study was obtained from all respondents. Their anonymity was also ensured, as well as restricted access to the research data - which was only available to the research team.

\section{Results}

A confirmatory factor analysis was conducted trying to replicate the Dutch model with 25 items. This initial model could not be estimated because of a collinearity problem between the sub-scales pertaining to Personal Efficacy, namely Personal Efficacy: General and Personal Efficacy: Context. Their differentiation among Portuguese teachers did not occur. Thus, we associated all nine items of both sub-scales directly to the Personal Efficacy factor. Table 2 shows the fit indexes for this initial model without other modifications. As item 1 ("I have a talent for teaching") was associated with two latent variables (Personal Efficacy and Interest), modification indexes suggested its elimination. Table 2 also presents indexes of the model's fit after the removal of item 1 .
Figure 1 presents the final model, in which, compared to the Dutch-language version, all items remain within their (sub)scales, except for the combined personal efficacy scale and the suppression of item 1. Two primary factors present loadings higher than .80 on the 'Motivation for Teaching' main scale, with Effort presenting a loading close to .80 (.78). Effort and Personal Efficacy present higher loadings in this general factor (Motivation for Teaching) than in the original questionnaire. The Teaching Efficacy (.19) and Outcome Efficacy (.50) factors are the weakest ones, especially the former. The latent factor called Personal Efficacy integrates Personal efficacy: Context and Personal Efficacy: General.

In synthesis, the Motivation for Teaching factor, as in the original model, is associated with all first-order factors, particularly with subscales related to motivational descriptors or related behaviors (Effort, Personal Efficacy, and Interest). This situation is not verified in the other two factors more associated to efficacy in the teaching practice (Teaching Efficacy and Outcome Efficacy, with loadings of .19 and .50 , respectively). At the same time, analyzing the loadings of the items in their specific factor, we can verify that the coefficients in general are higher than .60, expressing a strong relationship with the dimension evaluated by the firstorder factors. This does not apply to reverse-coded item 17 "I am not a very good teacher" on Personal Efficacy (.57). Perhaps in the future, if a reduction in the number of items is considered, this item could be eliminated or reformulated in a positive manner.

In Table 3 we present the score distributions by each subscale and global scale. We also present the items' internal consistency or reliability using ordinal $\alpha$ and $\omega$ coefficients.

Table 2

Results of the Confirmatory Factor Analysis

\begin{tabular}{lccccc}
\hline & CMIN/df & CFI & TLI & RMSEA & SRMR \\
\hline Portuguese Model (before modifications) & 4.930 & .888 & .946 & $.080[.076-.084]$ & 1.784 \\
Portuguese Model (without item 1) & 4.551 & .958 & .953 & $.76[.071-.080]$ & .57 \\
\hline
\end{tabular}

Note. CMIN/df= Minimum Discrepancy per Degree of Freedom; CFI = Comparative Fit Index; TLI = Tucker-Lewis Index; RMSEA = Root Mean Square Error of Approximation; SRMR = Standardized Root Mean Square Residual.

Table 3

Sub-scales Scores Distribution and Reliability

\begin{tabular}{|c|c|c|c|c|c|c|}
\hline Sub-scales & No. of items & Min - Max & $M$ & $S D$ & Ordinal $\alpha$ & $\omega$ \\
\hline Personal efficacy & 8 & $1.88-6.00$ & 5.18 & .59 & .921 & .886 \\
\hline Interest & 6 & $1.00-6.00$ & 5.26 & .71 & .932 & .911 \\
\hline Effort & 4 & $1.00-6.00$ & 5.33 & .79 & .881 & .843 \\
\hline Teaching efficacy & 3 & $1.00-6.00$ & 3.02 & 1.00 & .830 & .759 \\
\hline Outcome efficacy & 3 & $1.00-6.00$ & 3.83 & .86 & .839 & .768 \\
\hline General & 24 & $2.13-5.79$ & 4.78 & .51 & .930 & .944 \\
\hline
\end{tabular}




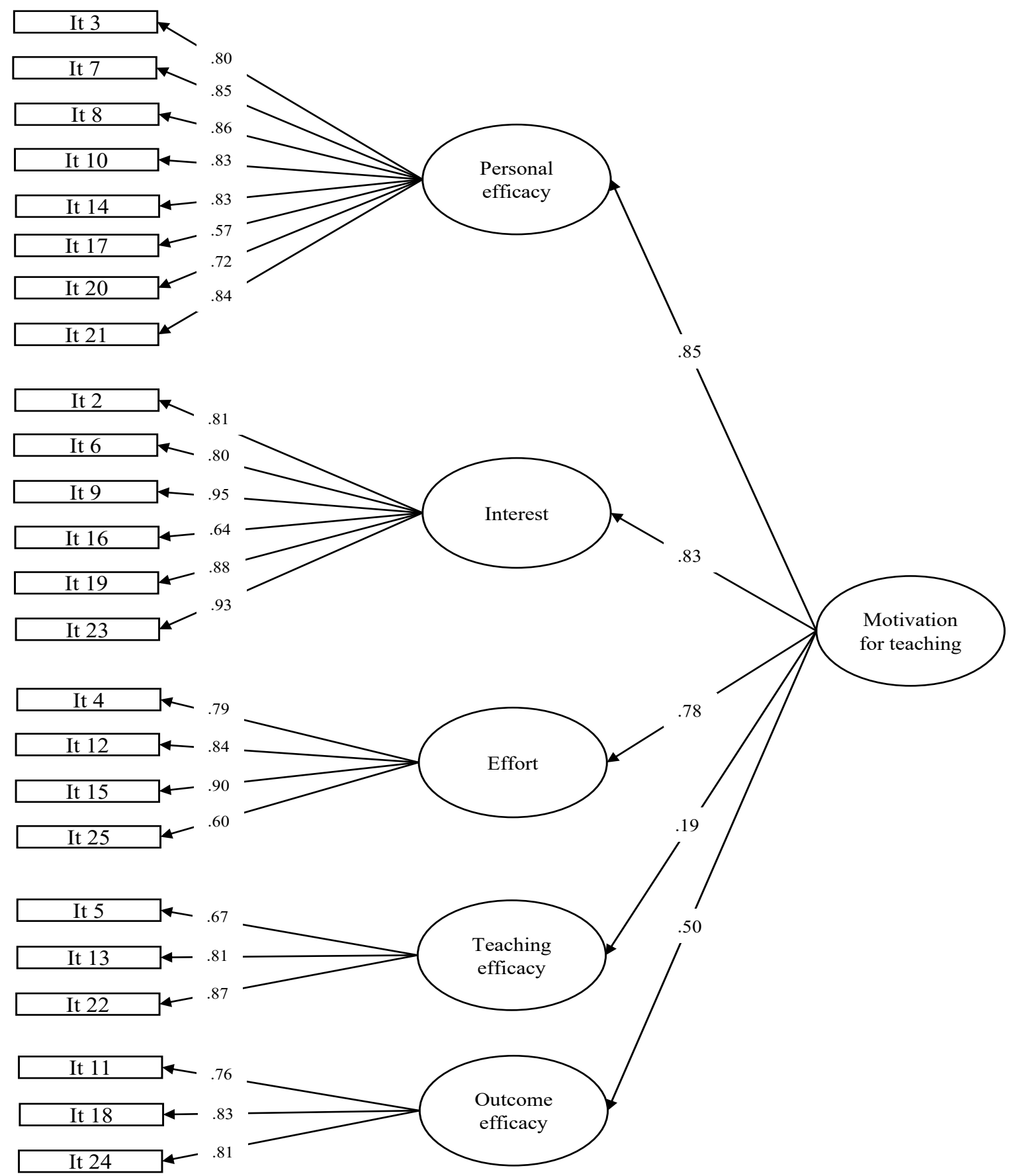

Figure 1. Factor Loadings of the Portuguese Model after Modifications.

In most sub-scales, the teachers position themselves between the minimum and maximum scores, except for Personal Efficacy, where the mean scores are situated between 1.88 and 6 in a 6-point Likert scale. Analyzing the scores' distributions, in all the other four dimensions, there is a single teacher who completely disagrees (1) with all the items and several who completely agree (6) with all the items. Even though there was a random distribution of the items' dimensions across the scale (see Table 1), this response pattern was still obtained. The teachers carry out positive selfassessments (mean scores above 5 on a 6-point scale) for the
3 sub-scales: Personal Efficacy, Interest, and Effort. A mean score below the scale's intermediate value (3.5) in the 6-point Likert scale was obtained for Teaching Efficacy; a mean score slightly above this value was obtained for Outcome Efficacy where we also find higher standard deviations, which reflects a higher score dispersion in the sample. In sum, there is a higher dispersion of the teachers' evaluations on Teaching Efficacy and a higher homogeneity on Personal Efficacy. The reliability coefficients (ordinal $\alpha$ and $\omega$ ) are higher than .75 (from .76 to .94), as desired; even in the Teaching Efficacy and Outcome Efficacy scales that only have three items. 


\section{Discussion}

The lack of relevance attributed to teaching compared to research in higher education teachers' careers is being increasingly questioned (Zabalza, 2007). At the same time, students have high expectations for active and participatory teaching and learning, and university teachers' value professional development for 'self-development' and pedagogical reasons (Veiga-Simão, Flores, Barros, Fernandes, \& Mesquita, 2015). Thus, it is important to study the personal resources that teachers use to make sense of and value their teaching practices; one of the most important being motivation for teaching. It is recognized that intrinsic motivation plays an important role in the recruitment and retention of teachers (Flores \& Niklasson, 2014), next to extrinsic factors such as working conditions, career opportunities, instructional support, and remuneration (Kiziltepe, 2008; Stankovska et al., 2017). Nonetheless, research focusing on personal and professional development of academics in higher education that associates motivation and efficacy to students' academic achievement is scarce and may profit from reliable and validated instruments to support an increasing number of studies.

Taking as its main objective the validation of an instrument for assessing motivation for teaching for Portuguese higher education teachers, our analysis shows that the internal structure of the questionnaire by VisserWijnveen et al. (2012) stands in its Portuguese version. This instrument takes a global construct for motivation that particularly embraces three dimensions (Personal Efficacy, Interest, and Effort). The CFA initial analysis showed that the differentiation of two basic factors (General Personal Efficacy and Context Personal Efficacy) included in a second order factor (Personal Efficacy) was not supported in the Portuguese sample because of a collinearity problem. So, the items included in both sub-scales were integrated in a single first order factor - Personal Efficacy. The apparent irrelevance of the specific context may be explained by a national tradition of binding teachers to a few number of specific curriculum units and this tendency is strengthened by their accumulating years of experience and position in the academic career.

With slight modifications, the CFA analysis presented an acceptable fit, supporting the theoretical model presented by Visser-Wijnveen et al. (2012). Basically, the removal of item 1 ("I have a talent for teaching") assured an acceptable fit. Perhaps "to have a talent" is not a straightforward assertion for teachers, as it can be taken as both a natural competence and a skill that can be developed. In addition, the fact that it is the first item in the questionnaire may have introduced some uncertainty in teachers at the beginning.

The results indicate that, as in the original model, motivation for teaching primarily consists of Personal Efficacy, Effort and Interest; Outcome Efficacy is of lesser relevance for motivation for teaching, while Teaching Efficacy showed an even lower loading. Thus, motivation is more associated to personal variables and internal focus like Effort, Interest and
Personal Efficacy than to context variables (Visser-Wijnveen et al., 2014). The analysis of the internal consistency coefficients shows values clearly above the required value (.75), even when the scales only have 3 to 4 items.

Looking at the results for Teaching Efficacy, on average, the teachers consider the influence of teaching on student learning slightly more important than their students' innate abilities. However, it should be noted that the teachers disagreed more on this sub-scale than on any other. For Outcome Efficacy, the teachers think that the students' results slightly improve because of their own actions as a teacher. Further discussion around the dimensions that really matter to motivation for teaching, especially in terms of clarifying the minor importance of Teaching Efficacy and Outcome Efficacy, is required, as these last two dimensions are less associated with motivation for teaching, while they specifically address the importance of the teacher, both in a general and personal manner, on the students' results (Zee \& Koomen, 2016). Our data suggest that efficacy related to impacting on the students' performance does not contribute as much to motivation for teaching, which is primarily explained by the general feeling of being a competent teacher, interest in the teaching activity, and putting effort into teaching. This is in line with the findings of Dybowski et al. (2017) showing no direct impact of teaching motivation or selfefficacy on teaching quality as perceived by the students, even though they recognize that teaching quality might benefit from training teachers in the ability to detect their students' competencies and from enhancing their teaching self-efficacy (Schneider \& Preckel, 2017).

Therefore, in spite of the impact of the current economic and financial crisis, which has resulted in reduced salaries, lack of promotions and of career advancement since 2004, the results indicate high levels of intrinsic motivation among higher education teachers in Portugal. This result complements the findings of Machado-Taylor et al. (2016) that revealed that, even though not very satisfied with their job, Portuguese academics are fairly motivated, especially younger ones (aged 30 or less) working in private institutions. Despite the worsening of the working conditions and the degradation of the academic career and salaries, Portuguese academics seem to remain intrinsically motivated, displaying higher levels of resilience.

Some suggestions for further studies in this area may be advanced. Based on the results, item 17 "I am not a very good teacher" should be worded in a positive way; however, this would reduce the number of reverse-coded items to zero, which also has its disadvantages. The advantages and disadvantages of keeping or removing (some) reverse-coded items need to be evaluated for each context. In addition, a differential study of the main factor may be carried out, taking into consideration teachers' personal variables like gender, scientific area, or teaching experience.

Some limitations of the study are identified. Only academics working in public institutions (representing $80 \%$ of the higher education institutions in Portugal) were asked 
to participate in the study. However, it would be important to understand the situation in the private sector. Therefore, in future studies, the sample and its diversity should be widened, seeking representative or more heterogeneous samples of the universe of higher education teachers in Portugal. In addition, an effort should be made to include less motivated teachers in future studies, as there is the possibility that, as the contact was by email, primarily highly motivated teachers participated in the study. Furthermore, it would be recommended to employ other methods together with this questionnaire to gain a more in-depth insight into higher education teachers' motivations as the risk of social desirability remains with self-reported questionnaires (El Alfy \& David, 2017; Han \& Yin, 2016).

Finally, it is important to advance further studies on motivation for teaching in higher education because of its relevance to the quality of the teaching and learning process. As high levels of staff motivation, interest, and perceived selfefficacy are related, it is possible to predict teachers' investment in providing quality learning experiences and academic success for their students; for the institutions, these studies may be used to predict gains in both institutional efficacy and widespread well-being. By comparing personal experiences and perceptions across countries, using empirical validated data, it is possible to advance in a deeper understanding of how to support teacher education, professional development, and institutional quality in higher education.

\section{References}

Aldridge, J. M., \& Fraser, B. J. (2016). Teachers' views of their school climate and its relationship with teacher self-efficacy and job satisfaction. Learning Environments Research, 19(2), 291-307. doi:10.1007/s10984-015-9198-X

Armor, D. J., Conry-Oseguera, P., Cox, M., King, N. J., McDonnell, L. M., Pascal, A. H., ... Zellman, G. L. (1976). Analysis of the school preferred reading programs in selected Los Angeles minority schools. Santa Monica, CA: Rand Corporation. Retrieved from https://www.rand.org/ content/dam/rand/pubs/reports/2005/R2007.pdf

Bandura, A. (1997). Self-efficacy: The exercise of control. New York, NY: Worth.

Bandura, A., Azzi, R. G., \& Polydoro, S. (2008). Teoria social cognitiva: Conceitos básicos [Cognitive social theory: Basic concepts]. Porto Alegre, RS: Artmed.

Bentler, P. M., \& Bonett, D. (1980). Significance tests and goodness of fit in the analysis of covariance structures. Psychological Bulletin, 88(3), 588-606. doi:10.1037/0033-2909.88.3.588

Blaskova, M., Blasko, R., Figurska, I., \& Sokol, A. (2015). Motivation and development of the university teachers' motivational competence. Procedia-Social andBehavioral Sciences, 182, 116-126. doi:10.1016/j.sbspro.2015.04.746
Deci, E. L., \& Ryan, R. M. (2008). Facilitating optimal motivation and psychological well-being across life's domains. Canadian Psychology, 49(1), 14-23. doi:10.1037/0708-5591.49.1.14

Dybowski, C., \& Harendza, S. (2015). Validation of the Physician Teaching Motivation Questionnaire (PTMQ). BMC Medical Education, 15, 166. doi:10.1186/s12909-015-0448-5

Dybowski, C., Sehner, S., \& Harendza, S. (2017). Influence of motivation, self-efficacy and situational factors on the teaching quality of clinical educators. BMC Medical Education, 17, 84. doi:10.1186/s12909-017-0923-2

ElAlfy, S., \& David, S. A. (2017). Investigating organisational justice in higher education in UAE. International Journal of Management in Education, 11(2), 163-187. doi:10.1504/IJMIE.2017.083355

Esdar, W., Gorges, J., \& Wild, E. (2015). The role of basic need satisfaction for junior academics' goal conflicts and teaching motivation. Higher Education, 72(2), 175-190. doi:10.1007/s10734-015-9944-0

Flores, M. A., \& Niklasson, L. (2014). Why do student teachers enroll for a teaching degree? A study of teacher recruitment in Portugal and Sweden. Journal of Education for Teaching: International Research and Pedagogy, 40(4), 328-343. doi:10.1080/02607476.2014.929883

Garcia, N. R., \& Boruchovitch, E. (2014). Atribuições de causalidade para o desempenho escolar e resiliência em estudantes [Causal attributions for school performance and resilience of students]. Psico-USF, 19(2), 277-286. doi:10.1590/1413-82712014019002003

Gibson, S., \& Dembo, M. H. (1984). Teacher efficacy: A construct validation. Journal of Educational Psychology, 76(4), 569-582. doi:10.1037/0022-0663.76.4.569

Gunersel, A. B., Kaplan, A., Barnett, P., Etienne, M., \& Ponnock, A. R. (2016). Profiles of change in motivation for teaching in higher education at an American research university. Teaching in Higher Education, 21(6), 628-643. doi:10.1080/13562517.2016.1163668

Han, J., \& Yin, H. (2016). Teacher motivation: Definition, research development and implications for teachers. Cogent Education, 3(1), 1217819. doi:10.1080/2331186X.2016.1217819

Hu, L.-T., \& Bentler, P. M. (1999). Cutoff criteria for fit indexes in covariance structure analysis: Conventional criteria versus new alternatives. Structural Equation Modeling: A Multidisciplinary Journal, 6(1), 1-55. doi:10.1080/10705519909540118

Iacobucci, D. (2009). Everything you always wanted to know about SEM (structural equations modeling) but were afraid to ask. Journal of Consumer Psychology, 19(4), 673-680. doi:10.1016/j.jcps.2009.09.002 
Inigo, M., \& Raufaste, E. (2019). Academics' motivations explain time-allocation and well-being at work. European Review of Applied Psychology, 69(1), 19-30. doi:10.1016/j.erap.2018.11.002

Katz, I., \& Shahar, B.-H. (2015). What makes a motivating teacher? Teachers' motivation and beliefs as predictors of their autonomy-supportive style. School Psychology International, 36(6), 575-588. doi:10.1177/0143034315609969

Kheir-Faddul, N., \& Dănăiaţă, D. (2019). The influence of leadership style on teachers' job motivation and satisfaction in the Druze sector of Israel. Timisoara Journal of Economics and Business, 12(1), 17-42. doi:10.2478/tjeb-2019-0002

Kiziltepe, K. (2008). Motivation and demotivation of university teachers. Teachers and Teaching, 14(5-6), 515-530. doi:10.1080/13540600802571361

Lam, W.-H. (2012). The study of teacher efficacy in Hong Kong sub-degree sector. Education Research International, 2012, 265293. doi:10.1155/2012/265293

Machado-Taylor, M. L., Soares, V. M., Brites, R., Ferreira, J. B., Farhangmehr, M., Gouveia, O. M. R., \& Peterson, M. (2016). Academic job satisfaction and motivation: Findings from a nationwide study in Portuguese higher education. Studies in Higher Education, 41(3), 541-559. doi:10.1080/03075079.2014.942265

Miller, A. D., Ramirez, E. M., \& Murdock, T. B. (2017). The influence of teachers' self-efficacy on perceptions: Perceived teacher competence and respect and student effort and achievement. Teaching and Teacher Education, 64, 260-269. doi:10.1016/j.tate.2017.02.008

O’Keefe, P. A., Dweck, C. S., \& Walton, G. M. (2018). Implicit theories of interest: Finding your passion or developing it? Psychological Science, 29(10), 1653-1664. doi:10.1177/0956797618780643

Oliden, P. E., \& Zumbo, B. D. (2008). Coeficientes de fiabilidad para escalas de respuesta categórica ordenada [Reliability coefficients for ordinal response scales]. Psicothema 20(4), 896-901. Retrieved from http://www.psicothema.com/pdf/3572.pdf

Palermo,C.,\&Thomson,M.M.(2019).Large-scaleassessment as professional development: Teachers' motivations, ability beliefs, and values. Teacher Development, 23(2), 192-212. doi:10.1080/13664530.2018.1536612

Pintrich, P. R., \& Schunk, D. H. (2002). Motivation in education: Theory, research, and applications. Upper Saddle River, NJ: Prentice-Hall.

Ramos, M. P. H., Ramos, E. M. L., Pontes, F. A. R., Casanova, D. C. G., Silva, S. S. C., \& Azzi, R G. (2018). Characterization of basic education teachers based on the Social Cognitive Model of Job Satisfaction. Paidéia (Ribeirão Preto), 28, e2811.doi:10.1590/1982-4327e2811
Raykov,T.(2001).Estimation of congeneric scalereliability using covariance structure analysis with nonlinear constraints. British Journal of Mathematical and Statistical Psychology, 54(Pt 2), 315-323. doi:10.1348/000711001159582

Saglam, A. C. (2007). Motivation of academics: An empirical assessment of Herzberg's theory. International Journal of Educational Reform, 16(3), 260-274. doi:10.1177/105678790701600302

Schiefele, U. (2009). Situation and individual interests. In K. R. Wentzel \& A. Wigfield (Eds.), Handbook of motivation at school (pp. 197-222). New York, NY: Routledge.

Schiefele, U., \& Schaffner, E. (2015). Teacher interests, mastery goals, and self-efficacy as predictors of instructional practices and student motivation. Contemporary Educational Psychology, 42, 159-171. doi:10.1016/j.cedpsych.2015.06.005

Skaalvik, E. M., \& Skaalvik, S. (2017). Motivated for teaching? Associations with school goal structure, teacher self-efficacy, job satisfaction and emotional exhaustion. Teaching and Teacher Education, 67, 152-160. doi:10.1016/j.tate.2017.06.006

Slavich, G. M., \& Zimbardo, P. G. (2012). Transformational teaching: Theoretical underpinnings, basic principles, and core methods. Educational Psychology Review, 24(4), 569-608. doi:10.1007/s10648-012-9199-6

Schneider, M., \& Preckel, F. (2017). Variables associated with achievement in higher education: A systematic review of meta-analyses. Psychological Bulletin, 143(6), 565- 600. doi: $10.1037 /$ bul0000098

Stankovska, G., Angelkoska, S., Osmani, F., \& Grncarovska, S. P. (2017). Job motivation and job satisfaction among academic staff in higher education. In N. Popov, C. Wolhuter, J. Kalin, G. Hilton, J. Ogunleye, E. Niemczyk, \& O. Chigisheva (Eds.), Current business and economics driven discourse and education: Perspectives from around the world (Vol. 15, pp. 159-166). Sofia, Bulgaria: Bulgarian Comparative Education Society.

Uiterwijk-Luijk, L., Krüger, M., Zijlstra, B., \& Volman, M. (2017). Inquiry-based leadership: The influence of affective attitude, experienced social pressure and self-efficacy. Journal of Educational Administration, 55(5), 492-509. doi:10.1108/JEA-12-2015-0114

Veiga-Simão, A.-M., Flores, M.-A., Barros, A., Fernandes, S., $\&$ Mesquita, D. (2015). Perceptions of university teachers about teaching and the quality of pedagogy in higher education: A study in Portugal. Infancia y Aprendizaje: Journal for the Study of Education and Development, 38(1), 102-143. doi:10.1080/02103702.2014.996408

Viseu,J.,Jesus,S.N.,Rus,C.,Canavarro,J.M.,\&Pereira,J.(2016). Relationship between teacher motivation and organizational variables: A literature review. Paidéia (Ribeirão Preto), 26(63), 111-120. doi:10.1590/1982-43272663201613 
Visser-Wijnveen, G. J., Stes, A., \& Van Petegem, P. (2012). Development and validation of a questionnaire measuring teachers' motivations for teaching in higher education. Higher Education, 64(3), 421-436. doi:10.1007/s10734-011-9502-3

Visser-Wijnveen, G. J., Stes, A., \& Van Petegem, P. (2014). Clustering teachers' motivations for teaching. Teaching in Higher Education, 19(6), 644-656. doi:10.1080/13562517.2014.901953

Weiner, B. (2000). Intrapersonal and interpersonal theories of motivation from an attributional perspective. Educational Psychology Review, 12(1), 1-14. doi:10.1023/A:1009017532121

Yada, A., Tolvanen, A., Malinen, O. P., Imai-Matsumura, K., Shimada, H., Koike, R., \& Savolainen, H.(2019). Teachers' self-efficacy and the sources of efficacy: A cross-cultural investigation in Japan and Finland. Teaching and Teacher Education, 81, 13-24. doi:10.1016/j.tate.2019.01.014

Zabalza, M. A. (2007). La enseñanza universitária: El escenario y sus protagonistas [University teaching: The scenery and its actors]. Madrid, España: Narcea.

Zee, M., \& Koomen, H. M. Y. (2016). Teacher self-efficacy and its effects on classroom processes, student academic adjustment, and teacher well-being: A synthesis of 40 years of research. Review of Educational Research, 86(4), 981-1015. doi:10.3102/0034654315626801

Leandro Silva Almeida, $\mathrm{PhD}$, is a Professor of University of Minho, Braga, Portugal.

Maria Alfredo Moreira, PhD, is a Professor of University of Minho, Braga, Portugal.

Suzana Nunes Caldeira, $\mathrm{PhD}$, is a Professor of University of Azores, Ponta Delgada, Portugal.

Sara Medeiros Soares, MA, is a Volunteer Researcher of University of Azores, Ponta Delgada, Portugal.

Natascha van Hattum-Janssen, $\mathrm{PhD}$, is a Quality Assurance Officer of Saxion University of Applied Sciences and Senior Researcher at the University of Twente, Enschede, the Netherlands.

Gerda J. Visser-Wijnveen, $\mathrm{PhD}$, is the Quality Assurance Manager of the Anton de Kom University of Suriname, Paramaribo, Suriname.
Authors' Contribution:

All the authors made substantial contributions to the conception and design of this study, to data analysis and interpretation, and to the manuscript review and approval of the final version. All the authors assume public responsibility for the content of the manuscript.

Associate editor:

Luciana Mourão Cerqueira e Silva

Received: Jun. 26, 2019

1st Revision: Nov. 01, 2019

2nd Revision: Apr. 09, 2020

3rd Revision: Jun. 26, 2020

4th Revision: Sep. 01, 2020

Approved: Sep. 03, 2020

How to cite this article:

Almeida, L. S. et al. (2021). Teachers' Motivation for Teaching in Higher Education: Portuguese validation of a questionnaire. Paidéia (Ribeirão Preto), 31, e3104.doi:https://doi.org/10.1590/1982-4327e3104 